- FINANSE I PRAWO FINANSOWE.

- Journal of Finance and Financial Law •

Marzec/March 2018 • vol. 1(17): 21-36

https://doi.org/10.18778/2391-6478.1.17.03

\title{
RELACJE UMOWNE NA PŁASZCZYŹNIE KONSUMENT \\ - BANK NA PRZYKŁADZIE 5 BANKÓW DZIAŁAJĄCYCH W POLSCE
}

\author{
Paweł Przerywacz \\ Wydział Ekonomiczno-Socjologiczny \\ Uniwersytet Łódzki
}

\begin{abstract}
Streszczenie
Obserwowany w ostatnich latach dynamiczny rozwój sektora bankowego determinuje sposób budowania relacji z interesariuszami banków. Do najistotniejszej grupy interesów należą klienci, nabywcy produktów i usług bankowych, których relacje z bankiem mogą stanowić istotny element przewagi konkurencyjnej. Należy przy tym wskazać, iż w porównaniu z bankami, ich prawa i obowiązki, choć precyzyjnie określone licznymi aktami prawnymi, wskazują na istotny dysonans pomiędzy pozycją pojedynczego klienta oraz banku jako instytucji finansowej w stosunku prawnym wyrażonym umową.
\end{abstract}

Celem publikacji jest ocena relacji bank - klient z punktu widzenia wyboru banku, rodzaju usług bankowych oraz przepisów prawa.

Słowa kluczowe: umowa, rachunek bankowy, konsument.

JEL Class: G21, G41. 


\section{WPROWADZENIE}

Rola klienta jest istotnym elementem w systemie bankowym. Produkty i usługi bankowe odgrywają istotną rolę $\mathrm{w}$ codziennym życiu oraz sposobie funkcjonowania zarówno większości osób fizycznych, jak i prawnych. Powszechny charakter oferty bankowej związany m.in. z jej dostępnością sprawia, że klienci banków, jako ich kluczowi interesariusze współkreują relacje z tymi podmiotami. Są one ustanowionew sposób formalny - nabycie produktu lub usługi bankowej poprzedzone jest podpisaniem odpowiedniej umowy, natomiast korzystanie $\mathrm{z}$ oferty, jest konsekwencją złożenia zlecenia lub dyspozycji [Marcinkowska 2013: 14].

Rachunki bankowe należą do najbardziej popularnych produktów bankowych. W dzisiejszych czasach konto osobiste jest nieodłącznym elementem naszego życia. Popularny rachunek bankowy jest rodzajem depozytu, dzięki któremu możemy przechowywać oszczędności. Charakteryzuje się bezpieczeństwem oraz łatwym dokonywaniem operacji. Przy wyborze odpowiedniego konta osobistego, głównymi kryteriami, na jakie zwracają konsumenci są: opłaty za korzystanie z konta, dodatkowe usługi oraz dostępność [Boczeń 2017, dostęp: 30.04.2017].

Celem publikacji jest ocena relacji bank - klient z punktu widzenia wyboru banku, rodzaju usług bankowych oraz przepisów prawa. Metody badawcze oparte były na studiach specjalistycznej literatury, branżowych czasopism, analizie aktów prawnych, ocenie przypadków.

\section{ANALIZA POJĘCIA KONSUMENTA W KONTEKŚCIE USŁUG BANKOWYCH}

Z początkiem lat 90 . w Polsce można zaobserwować bardzo duży wzrost zainteresowania konsumentów sektorem usług bankowych. Głównie dotyczy to rachunków oszczędnościowo-rozliczeniowych, tzn. popularnych ROR-ów (podobne znaczenie mają także umowy lokat terminowych oraz umowy kredytowe). Przyczynami takiego stanu rzeczy jest $\mathrm{z}$ jednej strony zainteresowanie konsumentów obrotem bezgotówkowym (przelewy, karty bankowe), wynikające z korzyści m.in. bezpieczeństwa, łatwości i szybkości przeprowadzania transakcji, z drugiej strony wymogiem zakładania rachunków, który stawiany był przez pracodawców czy ZUS, który zachęca emerytów do zakładania RORów [Raport o sytuacji ekonomicznej banków 2016, dostęp: 30.12.2017].

Pojęcie usług bankowych jest rozumiane bardzo szeroko. Obejmuje ono różnego rodzaju rachunki bankowe, umowy kredytowe, umowy pożyczek pieniężnych, operacje czekowe i wekslowe oraz inne operacje finansowe, przeprowadzanie bankowych rozliczeń pieniężnych, przechowywanie przedmiotów 
i papierów wartościowych czy udostępnianie skrytek sejfowych, czynności obrotu dewizowego [Srokosz 2009: 224-228; Srokosz 2000].

Fundamentalne $\mathrm{w}$ analizowanym temacie są relacje pomiędzy bankiem i konsumentem (klientem). W tym kontekście istotne znaczenie mają wymienione na wstępie, praktyczne aspekty związane m.in. z umowami rachunków oszczędnościowo-rozliczeniowych, umowami rachunków oszczędnościowych oraz umowami kredytowymi. W świetle polskiego prawa „Konsumentem” - zgodnie z przepisem art. $384 \S 3$ Kodeksu Cywilnego - ,jest osoba, zawierająca umowę $\mathrm{z}$ przedsiębiorcą $\mathrm{w}$ celu bezpośrednio niezwiązanym $\mathrm{z}$ działalnością gospodarczą, tzn. końcowy/ostateczny nabywca towarów lub usług, z których korzysta do zaspokojenia swoich osobistych, prywatnych potrzeb" [art. $384 \S 3$ Kodeksu Cywilnego]. Konsument w ustawodawstwie występuje w nieco innym charakterze niż pozostałe podmioty współtworzące obrót gospodarczy. Jednym z powodów takiego zróżnicowania jest dążenie do faktycznej (a nie tylko prawnej) równości stron umowy. Konsument jest bowiem najsłabszym ogniwem, biorąc pod uwagę coraz bardziej skomplikowany i wyspecjalizowany rynek.

Tabela 1. Podstawowe akty prawne w Polsce regulujące sposób świadczenia usług przez banki oraz ich zakres

\section{Kodeks Cywilny.}

Ustawa z dnia 23 kwietnia 1964 r. Kodeks Cywilny, tj. Dz.U. 1964, nr 16, poz. 93, z późn. zm. Księga III Zobowiązania - Tytuł III (Ogólne przepisy o zobowiązaniach umownych), Tytuł XX (Umowa rachunku bankowego), XXXVII (Przekaz i papiery wartościowe).

Ustawa z dnia 29 sierpnia 1997 r. - Prawo bankowe, tj. Dz.U. z 21 listopada, nr 140, poz. 939, z późn. zm.

Ustawa z dnia 14 grudnia 1994 r. o Bankowym Funduszu Gwarancyjnym, tj. Dz.U. 2000, nr 9, poz. 131 , z późn. $z m$.

Ustawa z dnia 29 sierpnia 1997 r. o listach zastawnych i bankach hipotecznych, tj. Dz.U. 1997, nr 140, poz. 940 ze zm., z późn. zm.

Ustawa z dnia 14 grudnia 1995 r. o spółdzielczych kasach oszczędnościowo-kredytowych, tj. Dz.U. 1996, nr 1, poz. 2, z późn. zm.

Ustawa z dnia 20 lipca 2001 r. o kredycie konsumenckim, tj. Dz.U. 2001, nr 100, poz. 1081, z późn. zm.

Ustawa z dnia 5 lipca 2002 r. o elektronicznych instrumentach płatniczych, tj. Dz.U. 2002, nr 169, poz. 1385, z późn. zm.

Źródło: opracowanie własne.

W rezultacie umowy zawierane są $\mathrm{z}$ jednej strony przez podmioty mające sztab specjalistów, świetnie orientujących się w danej dziedzinie, z drugiej strony przez konsumentów, czyli jednostki, które nie do końca są zorientowane 
w każdym obszarze swej działalności. Tym samym, niezwykle istotną kwestią jest potrzeba wzmocnienia ochrony konsumentów, co dotyczy w szczególności sektora bankowego. Bankowy obrót cywilnoprawny ma na celu łagodzenie i równoważenie wzajemnych interesów banku i klienta. W sposób szczególny dotyczy to konsumenta - istotą jest egzekwowanie zasady swobody kontraktowania, która powinna respektować w taki sam sposób prawa obu stron, bez względu na pozycję negocjacyjną i siłę partnera transakcji.

Regulacje, które przedstawia tab. 1 dotyczą przede wszystkim samej umowy - sposobu jej zawarcia, treści oraz doręczenia. Oprócz tego, istotną rolę odgrywa prawo do informacji. Ma to zapewniać m.in. dostępność i jasność regulaminów, uczciwa, rzeczowa reklama czy porównywalność ofert. Należy przy tym wskazać, iż oprócz ustaw, banki należące do polskiego sektora bankowego, muszą w swojej działalności uwzględniać m.in. rekomendacje Komisji Nadzoru Finansowego oraz dyrektywy organów Unii Europejskiej.

\section{SPECYFIKA UMÓW BANKOWYCH NA PRZYKŁADZIE POLSKIEGO SYSTEMU BANKOWEGO}

Artykuł 725 Kodeksu Cywilnego definiuje umowę rachunku bankowego. Stanowi on, że przez ,umowę rachunku bankowego bank zobowiązuje się względem posiadacza rachunku, na czas oznaczony lub nieoznaczony, do przechowywania jego środków pieniężnych oraz do przeprowadzania na jego zlecenie rozliczeń pieniężnych [Ustawa z dnia 23 kwietnia 1964 r. Kodeks Cywilny, Dz.U. 1964, nr 16, poz. 93, z późn. zm.]."

W tabeli 2 przedstawione są aspekty analizowanych umów zawieranych przez klienta $\mathrm{w}$ przypadku nabywania różnorodnych pod względem funkcjonalności i przeznaczenia rachunków bankowych. W bardzo ogólnym ujęciu konsumenci mają do wyboru umowy rachunku oszczędnościowego lub rachunku oszczędnościowo-rozliczeniowego [Ustawa z dnia 29 sierpnia 1997 r. - Prawo bankowe, tj: Dz.U. 2016, poz. 2260, z późn. zm.]. Stronami umowy są bank i posiadacz rachunku, natomiast przedmiotem umowy jest zobowiązanie się banku do przechowywania środków pieniężnych posiadacza rachunku oraz przeprowadzania na jego zlecenie rozliczeń pieniężnych. Zawarcie umowy rachunku idzie w parze $\mathrm{z}$ ogólnym obowiązkiem prowadzenia przez bank rachunku [Ustawa z dnia 29 sierpnia 1997 r. - Prawo bankowe, tj: Dz.U. 2016, poz. 2260, z późn. zm.]. Prócz tego bank obowiązany jest przy jednorazowej zmianie stanu rachunku bankowego przesyłać jego posiadaczowi wyciąg z rachunku $\mathrm{z}$ ustaleniem salda. Posiadacz rachunku obowiązany jest natomiast zgłosić bankowi ewentualną niezgodność salda [Ustugi bankowe w aspekcie ochrony praw 
konsumentów..., 2002, dostęp: 30.12.2017]. Umowa rachunku bankowego jest umową odpłatną, choć należy zauważyć, iż w wielu przypadkach świadome korzystanie przez klienta z produktu bankowego jest równoznaczne z możliwością uniknięcia opłat. Analizowane przepisy Kodeksu Cywilnego nie stanowią jedynego reżimu prawnego dla stosunku umownego dotyczącego rachunku bankowego. Mają tu zastosowanie również regulacje pozakodeksowe, spośród których zasadnicze znaczenie ma ustawa Prawo bankowe. Rozdział 3 tej ustawy reguluje kwestie związane $\mathrm{z}$ rachunkami bankowymi. Zgodnie z tymi przepisami otwarcie rachunku bankowego następuje przez zawarcie z bankiem umowy na piśmie.

Tabela. 2. Zestawienie części składowych umów rachunku bankowego oraz kredytu

\begin{tabular}{|c|c|c|}
\hline Wyszczególnione części składowe zawarte w umowach & $\begin{array}{c}\text { Rachunku } \\
\text { bankowego (ROR) }\end{array}$ & Kredytu \\
\hline Strony umowy & $\mathrm{x}$ & $\mathrm{x}$ \\
\hline Rodzaj otwieranego rachunku & $\mathrm{x}$ & \\
\hline Walutę, w jakiej rachunek/kredyt jest prowadzony/zawarty & $\mathrm{x}$ & $\mathrm{x}$ \\
\hline Czas, na jaki umowa została zawarta & $\mathrm{x}$ & $\mathrm{x}$ \\
\hline $\begin{array}{l}\text { Wysokość oprocentowania i warunki jego zmiany, wysokość } \\
\text { prowizji, jeżeli umowa je przewiduje }\end{array}$ & $\mathrm{x}$ & $\mathrm{x}$ \\
\hline Sposób dysponowania środkami zgromadzonymi na rachunku & $\mathrm{x}$ & \\
\hline $\begin{array}{l}\text { Terminy i sposób postawienia do dyspozycji kredytobiorcy } \\
\text { środków pieniężnych }\end{array}$ & & $\mathrm{x}$ \\
\hline Terminy wypłaty lub kapitalizacji odsetek & $\mathrm{x}$ & \\
\hline Zasady i termin spłaty kredytu & & $\mathrm{x}$ \\
\hline Terminy realizacji zleceń posiadacza & $\mathrm{x}$ & $\mathrm{x}$ \\
\hline $\begin{array}{l}\text { Zakres odpowiedzialności banku za terminowe i prawidłowe } \\
\text { przeprowadzanie rozliczeń pieniężnych oraz wysokość od- } \\
\text { szkodowania za przekroczenie terminu realizacji dyspozycji } \\
\text { posiadacza rachunku }\end{array}$ & $\mathrm{x}$ & \\
\hline $\begin{array}{l}\text { Sposób zabezpieczenia spłaty kredytu, zakres uprawnień banku } \\
\text { związanych z kontrolą wykorzystania i spłaty kredytu }\end{array}$ & & $\mathrm{x}$ \\
\hline Tryb i warunki dokonywania zmian umowy & $\mathrm{x}$ & $\mathrm{x}$ \\
\hline Sposób i termin wypowiedzenia lub rozwiązania umowy & $\mathrm{x}$ & $\mathrm{x}$ \\
\hline $\begin{array}{l}\text { Zasady rozwiązania umowy w razie niedokonywania na ra- } \\
\text { chunku żadnych obrotów }\end{array}$ & $\mathrm{x}$ & \\
\hline Cel, na który kredyt został udzielony & & $\mathrm{x}$ \\
\hline
\end{tabular}

Źródło: opracowanie własne na podstawie Ustawa z dnia 29 sierpnia 1997 r. - Prawo bankowe, tj. Dz.U. 2016, poz. 2260, z późn. zm.

Ponadto w umowie rachunku bankowego wskazuje się przepisy i sposób ustalania wysokości prowizji i opłat za czynności związane z prowadzeniem rachunku. Na podstawie art. 110 ustawy Prawo Bankowe, „banki mogą pobie- 
rać prowizje z tytułu wykonywanych czynności bankowych oraz opłaty za wykonywanie innych czynności” [Ustawa z dnia 29 sierpnia 1997 r. - Prawo bankowe, tj. Dz.U. 2016, poz. 2260, z późn. zm.]. Kolejny artykuł obliguje banki do ogłaszania w miejscu wykonywania czynności, w sposób ogólnie dostępny, informacji o stosowanych stawkach oprocentowania środków na rachunkach bankowych, kredytów i pożyczek, a zwłaszcza stawkach prowizji i wysokości opłat, terminach kapitalizacji odsetek oraz stosowanych kursach walutowych. Prócz tego, na podstawie art. 109 prawa bankowego, banki w obszarze swojej działalności mogą wydawać ogólne warunki umów lub regulaminy, w których szczegółowo określone są warunki otwierania i prowadzenia rachunków bankowych, rodzaje wkładów oszczędnościowych i warunki prowadzenia rachunków tych wkładów. Co istotne, postanowienia regulaminów bankowych są dla stron wiążące, jeżeli strony w umowie nie ustalą odmiennie swych praw i obowiązków.

Ustawa Prawo bankowe określa ponadto szczególne uprawnienia banków odnośnie umowy kredytowej. Banki uzależniają przyznanie kredytu od zdolności kredytowej kredytobiorcy, czyli od możliwości spłaty zaciągniętego kredytu wraz $\mathrm{z}$ odsetkami w określonych w umowie terminach. W okresie obowiązywania umowy kredytu, kredytobiorca obowiązany jest przedstawiać na żądanie banku informacje $\mathrm{i}$ dokumenty niezbędne do oceny jego sytuacji finansowej oraz umożliwiające kontrolę wykorzystania i spłaty kredytu. W momencie stwierdzenia przez bank kredytujący, że warunki udzielenia kredytu nie zostały dotrzymane lub w razie zagrożenia terminowej spłaty kredytu z powodu złego stanu majątkowego kredytobiorcy, bank ma prawo wypowiedzieć umowę kredytu w postaci: całości lub w części, bądź zażądać dodatkowego zabezpieczenia spłaty kredytu.

Przy interpretacji ogólnych warunków umów lub regulaminów zastosowanie mają także przepisy Kodeksu Cywilnego odnośnie niedozwolonych postanowień umownych. Niedozwolonymi postanowieniami umownymi są postanowienia nieuzgodnione wspólnie z konsumentem. Charakteryzują jego prawa i obowiązki w sposób sprzeczny z dobrymi obyczajami, rażąco naruszając jego interesy. Takie rezolucje są dla konsumenta niewiążące. Nie uwzględnia to jednak postanowień określających generalnych świadczeń stron, głównie cenę lub wynagrodzenie, jeżeli zostały sformułowane w sposób jednoznaczny [Ustawa z dnia 23 kwietnia 1964 r. Kodeks Cywilny, tj. Dz.U. 1964, nr 16, poz. 93, z późn. zm.].

Postanowienia umowy, na których treść konsument nie miał realnego wpływu to niezgodność indywidualna. Szczególnie dotyczy to postanowień umowy przejętych z wzorca umowy zasugerowanego konsumentowi przez kontrahenta. Ciężar dowodu, dotyczącego faktu, że postanowienie zostało uzgodnione indywidualnie, spoczywa na tym, kto się na ten fakt powołuje. Artykuł 
3853 Kodeksu Cywilnego zawiera listę przykładów niedozwolonych postanowień [Ustawa z dnia 23 kwietnia 1964 r. Kodeks Cywilny, tj. Dz.U. 1964, nr 16, poz. 93, z późn. zm.].

Jako niedozwolone postanowienia umowne, które zostały wymienione w przepisach, a które widnieją także w regulaminach stosowanych przez banki można przytoczyć przykłady takie jak [Konsumenci - Ochrona konsumentów - Niedozwolone klauzule, dostęp: 30.12.2017]:

1) postanowienia, które zezwalają kontrahentowi konsumenta na przeniesienia praw i przekazanie obowiązków wynikających z umowy bez zgody konsumenta,

2) postanowienia, które uprawniają kontrahenta konsumenta do jednostronnej zmiany umowy bez ważnej przyczyny wskazanej w tej umowie,

3) postanowienia, które przewidują uprawnienie kontrahenta konsumenta do określania lub podwyższania ceny lub wynagrodzenia po zawarciu umowy bez przyznania konsumentowi prawa odstąpienia od umowy,

4) postanowienia, które przewidują warunki, z którymi konsument nie miał możliwości zapoznać się przed zawarciem umowy,

5) postanowienia, które przyznają kontrahentowi konsumenta uprawnienia do dokonywania wiążącej interpretacji umowy.

Warto nadmienić, że jest to lista przykładowych niedozwolonych postanowień. Wynika z tego, że jako niedozwolone mogą być identyfikowane dodatkowo jeszcze inne postanowienia, jeżeli kwalifikują się w wyżej wymienionych warunkach, mianowicie nie są uzgodnione indywidualnie. Charakteryzują prawa i obowiązki konsumenta w sposób niezgodny $\mathrm{z}$ dobrymi obyczajami i rażąco naruszają jego interesy.

Porządek prawny dotyczący ogólnych warunków umów lub regulaminów dotyczą także oczywiście drugiej, istotnej dla konsumentów kategorii umów, to znaczy umów kredytowych. Kwestia ta została uregulowana w rozdziale 5 ustawy Prawo bankowe oraz w ustawie szczególnej o kredycie konsumenckim. Zgodnie z przepisami prawa bankowego przez umowę kredytu, bank jest zobowiązany oddać do dyspozycji kredytobiorcy na czas oznaczony w umowie kwotę środków pieniężnych z przeznaczeniem na ustalony cel, a kredytobiorca zobowiązuje się do korzystania z niej na warunkach określonych w umowie, zwrotu kwoty wykorzystanego kredytu wraz z odsetkami w oznaczonych terminach spłaty oraz zapłaty prowizji od udzielonego kredytu.

Poza tym dla relacji między bankami i konsumentami duże znaczenie mają także uchwały Związku Banków Polskich, np. uchwała w sprawie powołania Arbitra bankowego (także regulamin bankowego arbitrażu konsumenckiego) czy zasady dobrej praktyki bankowej. 


\section{MIEJSCE KONSUMENTA NA RYNKU BANKOWYM NA PRZYKŁADZIE 5 BANKÓW DZIAŁAJĄCYCH W POLSCE}

\subsection{Klienci polskich banków i ich konta osobiste}

Pod koniec 2016 roku w Polsce działało 38 banków komercyjnych. Profil działalności tych banków jest uniwersalny. W analizie uwzględnione 5 największych banków uniwersalnych działających w Polsce: PKO BP, Pekao, mBank, BZ WBK oraz ING Bank Śląski ze względu na znaczącą pozycję na polskim rynku wynikającą z posiadanych aktywów oraz liczby aktywnych klientów [Raport o sytuacji banków 2016, dostęp: 30.12.2017].

Klienci odgrywają niezwykle istotną rolę w funkcjonowaniu firm. Dostarczają firmom wpływów pieniężnych oraz ważnych wartości. Pozyskane od klientów wartości pozwalają firmom pogłębiać relacje z innymi uczestnikami rynku, takimi jak akcjonariusze, dostawcy czy pracownicy. Rynek usług bankowych w Polsce rośnie dynamicznie $\mathrm{z}$ roku na rok. W analizie uwzględniany jest indywidualny klient. Wynika to m.in. ze wzrostu posiadanych aktywów proporcjonalnie do wzrostu liczby klientów w bankach. Ze względu na bardzo konkurencyjne oferty banki przyciągają i zabiegają o klienta, by skorzystał z ich oferty i założył swoje pierwsze konto, a następnie nabył dodatkowe produkty [Doligalski 2013: 16-20].

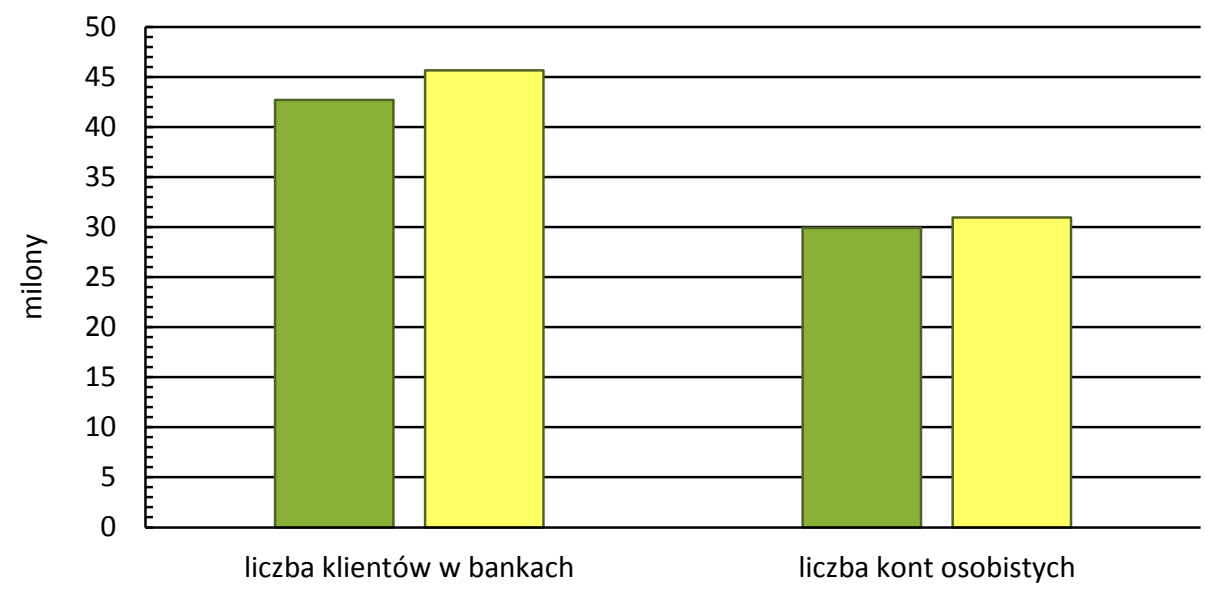

口IV kw 2015 IV kw 2016

Wykres 1. Liczba klientów w bankach oraz kont osobistych w IV kwartałach 2015 i 2016

Źródło: Boczeń 2017 [dostęp: 30.04.2017]. 
Z wykresu 1 wynika, że w 2015 roku liczba klientów w bankach wynosiła ok. 43 mln osób, zaś już pod koniec 2016 roku było to prawie 46 mln aktywnych klientów. Liczba kont osobistych w 2015 roku wynosiła prawie $30 \mathrm{mln}$, natomiast $\mathrm{w} 2016$ również z tendencją podobną do wzrostu klientów, wynosiła prawie $31 \mathrm{mln}$ aktywnych rachunków bankowych. Warto zwrócić uwagę na to, że pojedynczy klient może posiadać kilka rachunków w różnych bankach, również dotyczy to innych produktów bankowych.

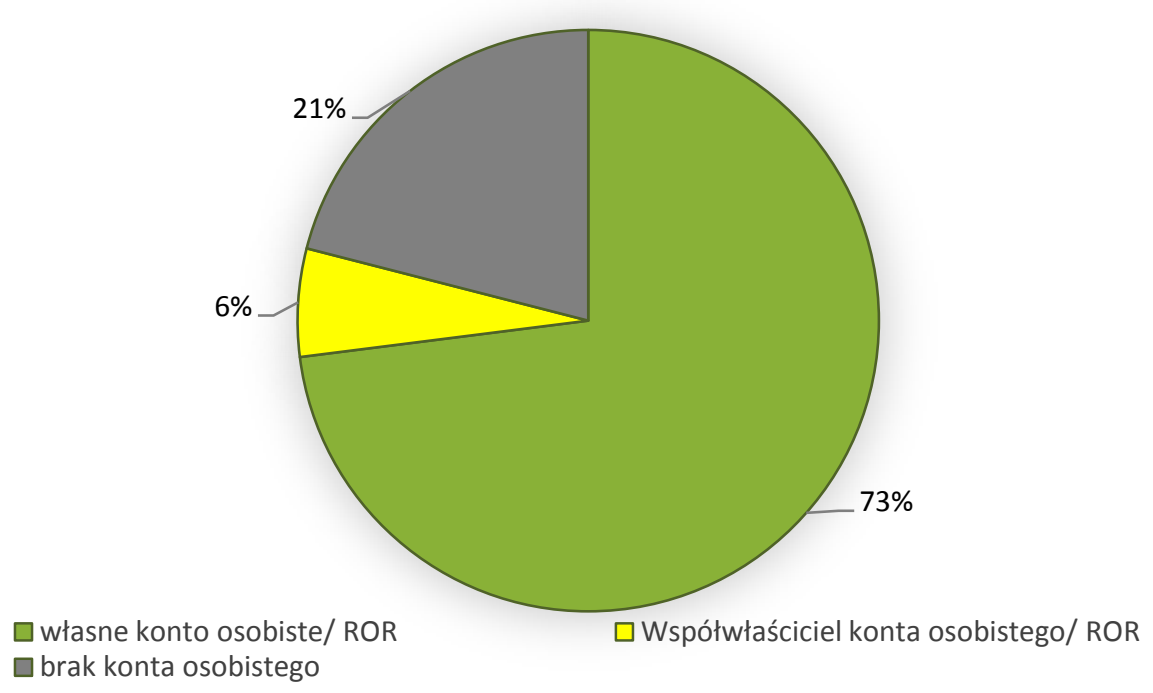

Wykres 2. Posiadane konta osobistego/ROR przez Polaków w 2016

Źródło: Boczeń 2017 [dostęp: 30.12.2017].

Według informacji z wykresu 2 wynikającego z badania przeprowadzonego na ogólnopolskiej losowej próbie 970 Polaków przez Departament Systemu Płatniczego NBP, własne konto posiada 73\% respondentów, aż $6 \%$ jest współwłaścicielem takiego konta osobistego, bądź ROR, zaś $21 \%$ nie posiada w ogóle konta osobistego.

\subsection{Formy umów 5 badanych banków z klientami}

Warto zwrócić uwagę, że coraz częściej przeprowadzane badania pokazują, że ponad $70 \%$ społeczeństwa posiada dostęp do konta osobistego w banku. Duże banki w Polsce zdobywają rynek usług bankowych, specjalizując się w poszczególnych produktach bankowych, co przekłada się na rosnący udział w rynku. 
Klient jako wartość dla banku generuje zysk. Na decyzję o wyborze banku przez klienta często wpływa pozycja danego banku na rynku. Liderzy danych usług bankowych, również są liderami w całym sektorze, co świadczy o prestiżu.

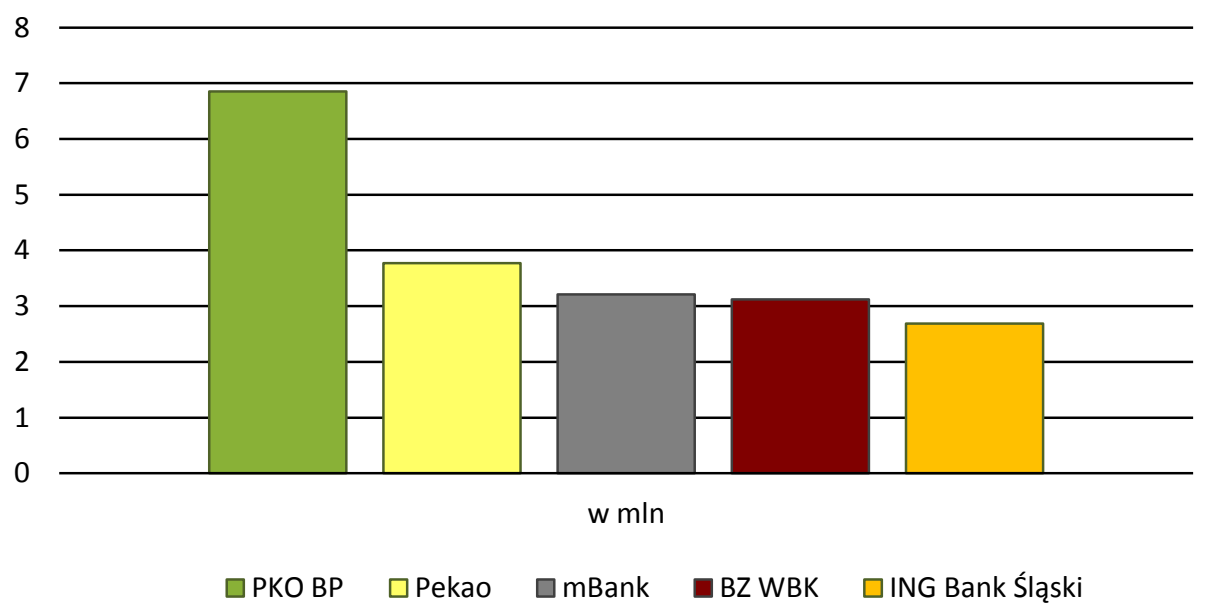

Wykres 3. Liczba aktywnych ROR w 5 bankach działających w Polsce w IV kwartale 2016

Źródło: Boczeń 2017 [dostęp: 30.12.2017].

Jak widać na wykresie 3, największy bank w Polsce - PKO BP ma przeważający udział na rynku. Posiadając rachunek bankowy konsument „,zaopatruje się" w nowe produkty bankowe, co pozwala na poszerzanie skali działalności banku. Jednakże nieco ponad $20 \%$ nie posiada takiego rachunku, co może wynikać z braku akceptacji oraz pewnych dotychczasowych przyzwyczajeń w życiu głównie przez osoby starsze. Drugi bank na rynku - Pekao posiada niewiele ponad połowę aktywnych ROR w porównaniu do PKO BP. Konsument decydujący się na założenie rachunku zwraca uwagę na konkurencyjne warunki oprocentowania oraz opłaty. Na dzisiejszym rynku funkcjonuje wiele programów polecających otwarcie, które proponują dodatkowy zysk.

Konsumenci zakładając konto $\mathrm{w}$ banku korzystają z dodatkowych produktów m.in. z popularnych kart kredytowych. Na wykresie 4 widzimy, że w PKO BP jest ponad 800 tyś. aktywnych kart kredytowych. Podium 3 banków pokazuje, że banki w swoich zasobach posiadają podobną liczbę aktywnych kart kredytowych. Klienci wybierający ofertę karty kredytowej zwracają uwagę czy wydanie karty przypisanej do konta jest darmowe, czy też nie. W następnej kolejności biorą pod uwagę oprocentowanie oraz prowizję pobieraną przy udostępnianiu limitu kredytowego. 


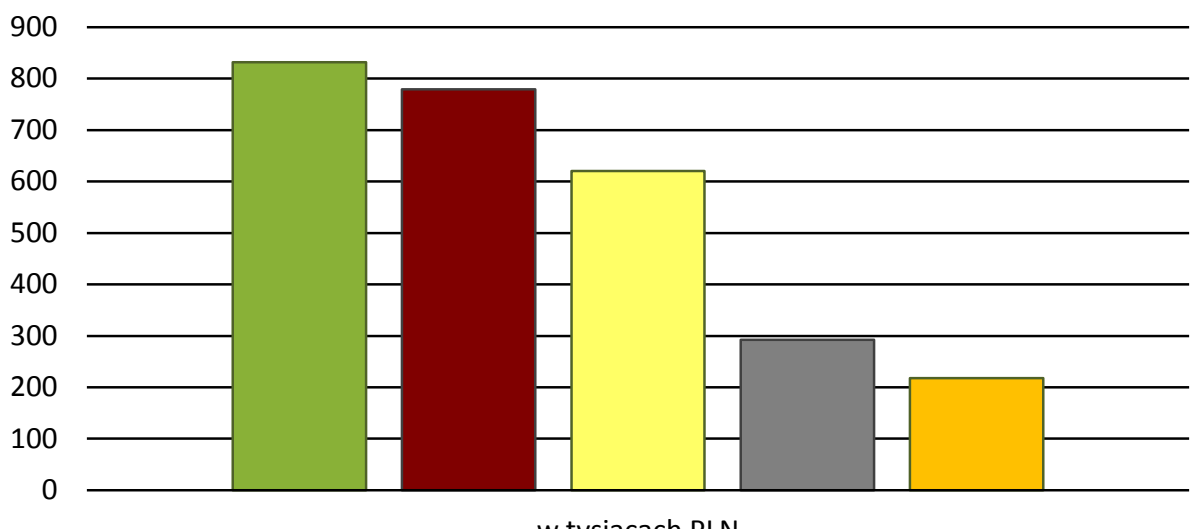

w tysiącach PLN

$\square$ PKO BP $\square$ BZ WBK $\square$ Pekao $\square$ mBank $\square$ ING Bank Śląski

Wykres 4. Liczba aktywnych kart kredytowych w 5 bankach działających w Polsce w IV kwartale 2016

Źródło: Boczeń 2017 [dostęp: 30.12.2017].

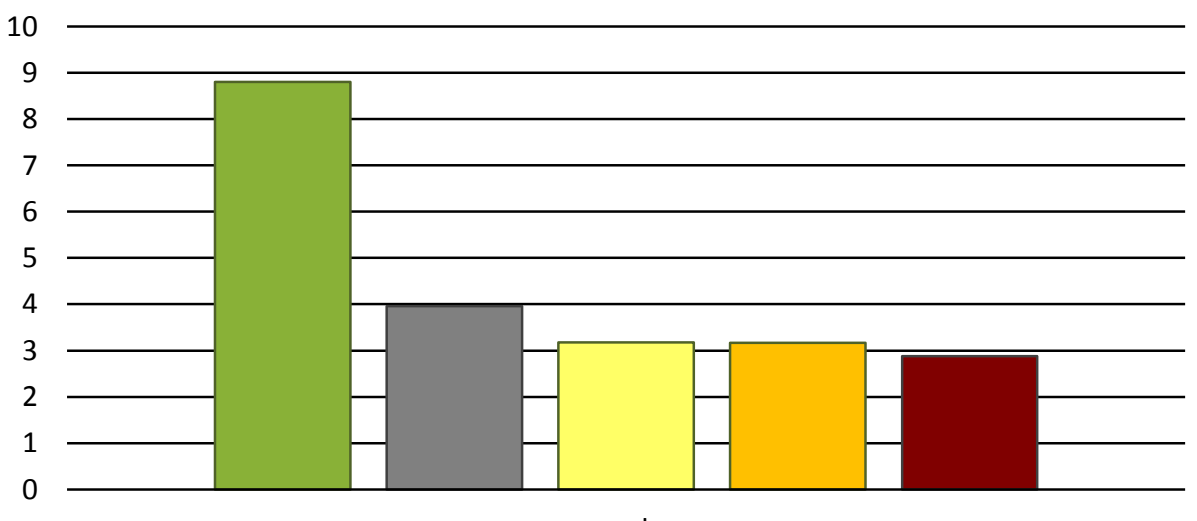

w mln

$\square$ PKO BP $\square$ mBank $\square$ Pekao $\quad \square$ ING Bank Śląski $\quad$ BZ WBK

Wykres 5. Liczba klientów indywidualnych mających podpisaną umowę umożliwiającą korzystanie z bankowości internetowej w Polsce w IV kwartale 2016

Źródło: Boczeń 2017 [dostęp: 30.12.2017]. 
Z wykresu 5 wynika, że PKO BP posiadający największą liczbę aktywnych indywidualnych rachunków, również jest liderem pod względem liczby osób korzystających z bankowości internetowej. Wiodący bank posiada zarejestrowanych prawie 9 mln takich umów, zaś mBank ponad połowę mniej - $4 \mathrm{mln}$, pozostałe banki biorące w rankingu po $3 \mathrm{mln}$. Korzystanie $\mathrm{z}$ bankowości internetowej pozwala skrócić czas wykonywania czynności bankowych. Klienci częściej sami robią przelewy, płacąc za rachunki czy płacąc za zakupy w Internecie.

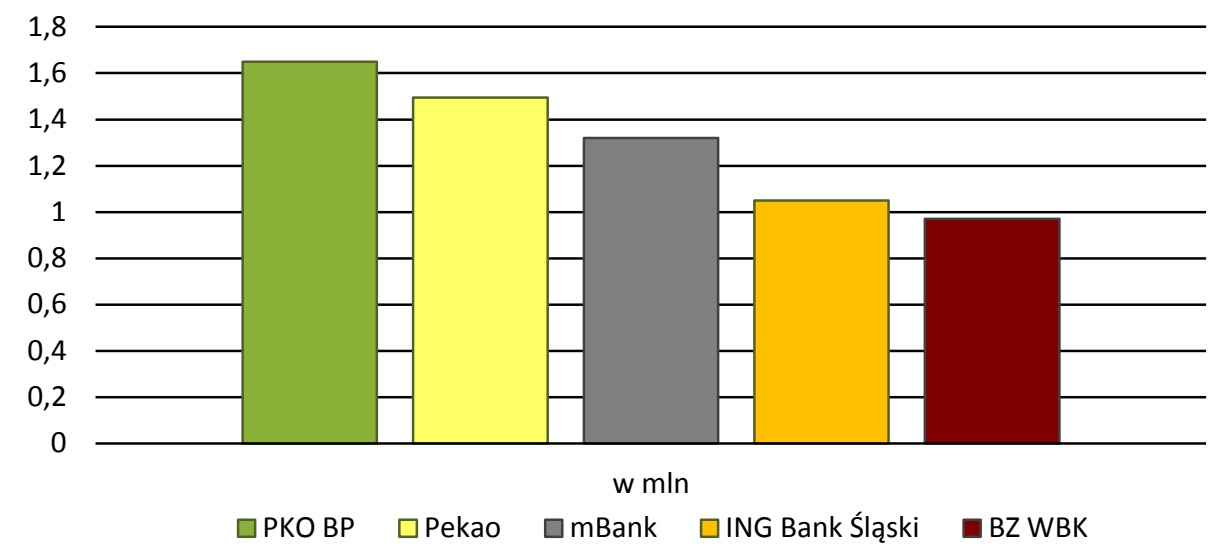

Wykres 6. Liczba użytkowników bankowości mobilnej, którzy aktywnie korzystają z usług banku z poziomu urządzenia mobilnego w IV kwartale 2016

Źródło: Boczeń 2017 [dostęp: 30.12.2017].

Na podstawie wykresu 6 - największy bank w Polsce posiada ponad 1,6 mln klientów, którzy aktywnie korzystają z bankowości mobilnej. Zaraz za nim plasują się 2 banki, które posiadają ponad $1 \mathrm{mln}$ aktywnych użytkowników. W Polsce ten kanał kontaktu $\mathrm{z}$ bankiem i korzystaniu $\mathrm{z}$ jego usług rozwija się i prym wiodą $\mathrm{w}$ tym największe banki. Jest to wielka wygoda dla klienta, gdy załatwianie wszystkich płatności może wykonać za pośrednictwem smartfona. Szczególnie młodzi użytkownicy skupiają się na tych bankach, które oferują atrakcyjne i przyjazne dla użytkownika aplikacje.

Pomimo mobilności oraz szerokiego dostępu do usług finansowych Polacy nie są gotowi zrezygnować z tradycyjnego kontaktu z bankiem. Na podstawie wykresu 7 największy bank w Polsce posiada ponad 1200 placówek, następne banki biorące udział w zestawieniu kolejno mniej niż 1000. Branża bankowa ograniczać będzie w przyszłości rozbudowę sieci tradycyjnych, a skupiać się ma na mobilności i kontakcie za pośrednictwem Internetu. 


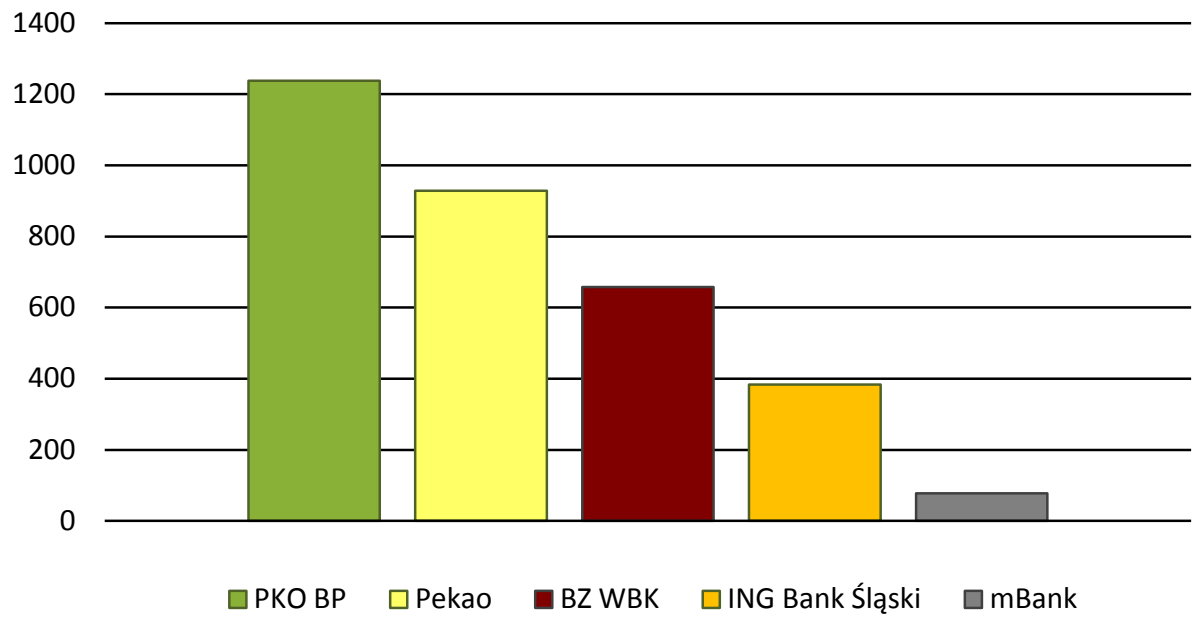

Wykres 7. Liczba placówek własnych banków w Polsce w IV kwartale 2016

Źródło: Boczeń 2017 [dostęp: 30.12.2017].

\section{PODSUMOWANIE}

Problematykę stosunków umownych konsumenta $\mathrm{z}$ bankiem reguluje szereg aktów prawnych. Na złożoność sprawy wpływa to, że nie są ujęte w jednym wyodrębnionym zbiorze przepisów. Interpretując oraz oceniając umowy zawierane z bankami należy stosować równocześnie przepisy Kodeksu Cywilnego (wzorce umów, umowa rachunku bankowego), ustawy Prawo bankowe oraz ewentualnie przepisy ustaw szczególnych, np. ustawy o kredycie konsumenckim lub o elektronicznych instrumentach płatniczych.

Konsument jako uczestnik rynku, którego jednostkowa pozycja nie pozwala na kształtowanie zapisów umów, nie może zostać pozostawiony bez wsparcia i pomocy, szczególnie na rynku usług finansowych, kiedy to zawierane są umowy, w których po jednej ze stron jest bank, jako przedsiębiorca dążący do maksymalizacji zysku w najkrótszym przedziale czasowym, przy minimalizacji ryzyka i towarzyszących mu kosztów, a z drugiej strony słabszy na tym rynku konsument tych usług. Powstało zatem wiele inicjatyw i programów wsparcia konsumenta na rynku finansowym. Jednostka, w ocenie której bank nie wywiązuje się z części lub wszystkich postanowień umowy, może skorzystać z pomocy m.in. rzecznika konsumentów, arbitra bankowego przy Związku Banków Polskich lub Komisji Nadzoru Finansowego. 
Możliwość uzyskania pomocy w organizacjach i jednostkach stanowiących otoczenie sektora bankowego, sprawia, iż konsument na rynku usług finansowych nie pozostaje osamotniony w egzekwowaniu swoich praw. Co więcej, pomocne $\mathrm{w}$ rozstrzygnięciu sporu $\mathrm{z}$ bankiem może okazać się skorzystanie ze wsparcia (np. prawnego) więcej niż jednego organu. Liczby wskazują, iż wiele spraw rozstrzyganych jest polubownie, a koszty całego postępowania są niewielkie [www1]. Tym samym, droga sądowa staje się ostatecznością, której instytucje finansowe, a zwłaszcza banki jako instytucje zaufania publicznego, starają się unikać.

W analizie uwzględniono działalności 5 banków uniwersalnych działających w Polsce: PKO BP, Pekao, mBank, BZ WBK oraz ING Bank Śląski. Banki te na tle sektora wyróżnia to, że są największymi instytucjami ze względu na znaczącą pozycję na polskim rynku wynikającą z posiadanych aktywów oraz liczby aktywnych klientów.

Kluczem do znalezienia najlepszego banku są produkty, które będą dostosowane do potrzeb klienta. $Z$ reguły banki dbają o swoich stałych klientów i dają im lepsze warunki produktowe. A zatem, jeśli dziś wybierzemy daną instytucję i np. założymy konto, to w przyszłości oferta kredytu będzie dla nas korzystniejsza, niż dla klientów z zewnątrz. Najczęściej zawieranymi umowami bankowy$\mathrm{mi}$ są te związane $\mathrm{z}$ rachunkiem oszczędnościowo-rozliczeniowym. W praktyce banki pozycjonują się na klientach, którzy są związani więcej niż z jednym produktem. Wcale nie trzeba być klientem banku od roku czy pięciu lat, by zasłużyć na preferencyjne warunki. W bardzo wielu bankach podczas zaciągania kredytu lub zakładania konta, proponuje się klientowi wykupienie innego produktu: karty do konta, karty kredytowej, pożyczki gotówkowej - w zamian za np. obniżenie oprocentowania kredytu - tzw. sprzedaż wiązana (cross selling).

Nie jest tajemnicą, że potrzebując pieniędzy, bank odgrywa znaczącą rolę w życiu klienta. Klient musi zaznajomić się z opłatami, ponieważ przed wyborem banku każdorazowo należy zapoznać się z cennikiem opłat i prowizji. Każdy bank taki dokument posiada, udostępnia go na stronie internetowej oraz każdej placówce banku. To prawdopodobnie jedno z najważniejszych kryteriów, jakimi powinien się kierować konsument wybierając bank, któremu powierzać będziemy pieniądze. Należy więc sprawdzić, ile kosztować będzie: miesięczna opłata za prowadzenie konta, jednorazowy przelew, karta do bankomatu, zlecenie stałe, wypłata gotówki w kasie banku. Klient szuka banku, w którym te opłaty są minimalne lub nawet zerowe. Wielu klientów w podeszłym wieku zwraca uwagę na to czy placówka banku znajduje się blisko ich domu. Jednakże osoby $\mathrm{z}$ reguły bardziej zaznajomione $\mathrm{z}$ nowinkami technicznymi i komputerem szczególnie zwracają uwagę na nowoczesną bankowość, w której większość operacji wykonujemy przez Internet bądź za pośrednictwem aplikacji. Jednocześnie dla pewnego odsetka klientów ważna jest duża jest sieć własnych bankomatów 
i bankomatów partnerskich, w których nie jest pobierana opłata za wypłacanie pieniędzy. Tacy konsumenci zwracają uwagę na koszty wypłaty gotówki w obcym bankomacie (wiele banków oferuje już darmowe wypłaty w dowolnym bankomacie) oraz wypłata z bankomatu za granicą.

Uwzględniając poziom mikro relacji pomiędzy bankiem i klientami, finalny konsument na rynku usług bankowych odgrywa istotną rolę, bowiem na nim, jako najmniejszej jednostce w pewnym sensie opiera się cały system. Dlatego tak ważna jest konstrukcja systemu instytucjonalnego, która będzie chronić interesów i praw konsumentów oraz będzie gwarantowała uczciwość i przestrzeganie zasad obrotu gospodarczego w dziedzinie usług bankowych. Złożoność procesów ukazuje ulokowanie konsumenta na rynku usług finansowych, jednakże wciąż nierozwiązany pozostaje problem egzekwowania tych praktyk oraz prawidłowego ich stosowania. Wyjątkowo istotny jest stosunek prawny, określający relacje banku z klientami. Akcentowane jest głównie indywidulane podejście, uwzględniające w szczególności sytuację życiową i finansową konsumenta. Tym samym obserwowana ewolucja bankowości relacyjnej może doprowadzić do ukształtowania się nowego podejścia w zakresie usług bankowych, w szczególności w aspekcie relacji pomiędzy bankami i konsumentami.

\section{BIBLIOGRAFIA}

Boczeń W., 2017, Polska Bankowość w liczbach, Bankier.pl, http://www.bankier.pl/static/att/ 147000/7511698_bpl_raport_bankowosc_2016.pdf [dostęp: 30.12.2017].

Doligalski T., 2013, Internet $w$ zarządzaniu wartościa klienta, Oficyna Wydawnicza SGH, Warszawa.

Konsumenci - Ochrona konsumentów - Niedozwolone klauzule, Urząd Ochrony Konkurencji i Konsumentów, https://www.uokik.gov.pl/download.php?plik=11170 [dostęp: 30.12.2017].

Marcinkowska M., 2013, Kapitat relacyjny banku, t. 2, Relacje banku z kluczowymi interesariuszami, Wydawnictwo Uniwersytetu Łódzkiego, Łódź.

Raport o sytuacji ekonomicznej banków 2016, ZBP, https://www.wib.org.pl/uploaded/Raport\%20Banki\%202016.pdf [dostęp: 30.12.2017].

Raport o sytuacji banków 2016, Urząd Komisji Nadzoru Finansowego, https://bip.knf.gov.pl/pliki/RAPORT_O_SYTUACJI_BANKOW_2016_59975_tcm659975.pdf [dostęp: 30.12.2017].

Srokosz W., 2000, Pojęcie ustug finansowych $w$ regulacjach prawnych Unii Europejskiej, „Pr. Bank”, nr 9.

Srokosz W., 2009, [w:] E. Fojcik-Mastalska (red.), Prawo bankowe, Wrocław.

Ustugi bankowe $w$ aspekcie ochrony praw konsumentów Raport z kontroli wzorców umownych uznanych za niedozwolone, 2002, Urząd Ochrony Konkurencji i Konsumentów, Warszawa, https://uokik.gov.pl/download.php?plik=1121 [dostęp: 30.12.2017].

Ustawa z dnia 23 kwietnia 1964 r. Kodeks Cywilny, tj. Dz. U. 1964, nr 16, poz. 93, z późn. zm.

Ustawa z dnia 29 sierpnia 1997 r. - Prawo bankowe, tj. Dz.U. z 21 listopada, nr 140, poz. 939, z późn. zm. 
Ustawa z dnia 14 grudnia 1994 r. o Bankowym Funduszu Gwarancyjnym, tj. Dz.U. 2000, nr 9, poz. $131, \mathrm{z}$ późn. zm.

Ustawa z dnia 29 sierpnia 1997 r. o listach zastawnych i bankach hipotecznych, tj. Dz.U. 1997, nr 140, poz. 940 , z późn. zm.

Ustawa z dnia 14 grudnia 1995 r. o spółdzielczych kasach oszczędnościowo-kredytowych, tj. Dz.U. 1996, nr 1, poz. 2, z późn. zm.

Ustawa z dnia 20 lipca 2001 r. o kredycie konsumenckim, tj. Dz.U. 2001, nr 100, poz. 1081, z późn. zm.

Ustawa z dnia 5 lipca 2002 r. o elektronicznych instrumentach płatniczych, tj. Dz.U. 2002, nr 169, poz. 1385 , z późn. zm.

[www1] https://www.mfind.pl/akademia/dochodzenie-odszkodowan/pozasadowe-rozstrzyganiesporow [dostęp: 30.12.2017].

\title{
CONTRACTUAL RELATIONS AT THE CONSUMER LEVEL - A BANK ON THE EXAMPLE OF 5 BANKS OPERATING IN POLAND
}

\begin{abstract}
The dynamic development of the banking sector observed in recent years determines the method of building relationships with bank stakeholders. The most important interest groups are customers, purchasers of banking products and services whose relations with the bank may constitute an important element of competitive advantage. It should be noted that in comparison with banks, their rights and obligations, although precisely defined by numerous legal acts, indicate a significant dissonance between the position of a single customer and a bank as a financial institution in a legal relation expressed in the contract.

The aim of the publication is to assess the bank-client relationship from the point of view of the bank's choice, the type of banking services and the law.
\end{abstract}

Keywords: contract, bank account, consumers. 